УДК 622.26, https://doi.org/10.37878/2708-0080/2021-2.06

\title{
АНАЛИЗ ОТКЛОНЕНИЙ ТРАЕКТОРИЙ СТВОЛОВ ГОРИЗОНТАЛЬНЫХ И НАКЛОННО-НАПРАВЛЕННЫХ СКВАЖИН ОТ ИХ ПРОЕКТНЫХ ПРОФИЛЕЙ
}

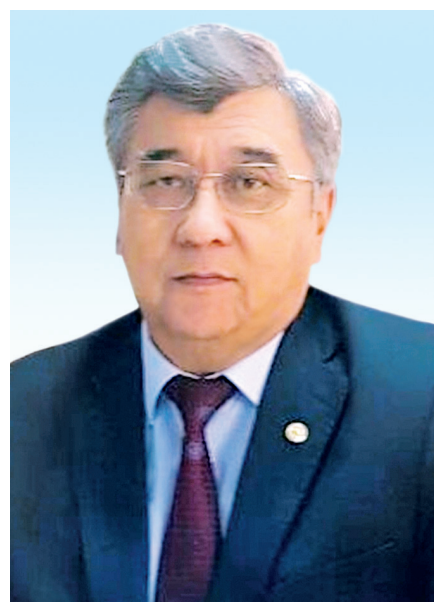

Ж.Г. ШАЙХЫМЕЖДЕНОВ*, доктор технических наук, профессор, член-корреспондент НИА РК, https://orcid.org/0000-0002-2290-1040

КАЗАХСКИЙ УНИВЕРСИТЕТ ТЕХНОЛОГИИ И БИЗНЕСА

г. Нур-Султан, район Есиль, ул. Кайым Мухамедханова,здание 37 А.

В работе представлен анализ промысловых материалов по отклонениям от проектных траекторий стволов при проводке наклонно-направленных, горизонтальных скважин (ГС) и скважин по зарезкебоковых стволов с горизонтальным окончанием (ЗБГС) по рассмотренным месторождениям. Результаты показывают на наличие большого количества скважин завершенных бурением с отклонениями от проектного профриля. Приведены фракты о не корректном заполнении фрактических инклинометрических замеров, а также из-за неясностей в заполненных данных о замерах, профили скважин в ПО «Petrel» загружались без учета поправки направления (П Н), которые привели к смещению забоев многих скважин в моделях по отношению к заданным. Для предотвращения указанных случаев в заключении работы даны соответствующие рекомендации.

КЛЮЧЕВЫЕ СЛОВА: профрили скважин, горизонтальные скважины (ГС), отклонения от проектного профиля, инклинометрические замеры, ПО «Petrel», поправки направления (П Н), смещение забоев скважин в моделях.

\section{КӨЛДЕНЕН ОҚПАНДАР ЖӘНЕ КӨЛБЕУ БАҒЫТТАЛҒАН ҰНҒЫМАЛАРДЫН ТРАЕКТОРИЯЛАРЫНЫН ЖОБАЛЫҚ ПРОФИЛЬДЕН АУЫТҚУЫН ТАЛДАУ}

*Адрес для переписки. E-mail: zhshaikhymezhdenov@mail.ru 
Ж.Г. ШАЙХЫМЕЖДЕНОВ*, техника ғылымдарының докторы, профессор, ҚР ҰИҒА корр. мүшесі, https://orcid.org/0000-0002-2290-1040

КАЗАҚ ТЕХНОЛОГИЯ ЖӘНЕ БИЗНЕС УНИВЕРСИТЕТІ

Нұр-Султан қаласы, Есіл ауданы, Қайым Мухамедханов көшесі, ғимарат 37А

Бұл жұмыста таңдалған бірқатар кен орындары бойынша көлбей бағытта, көлденең (КҰ) және оқпан бүйірінен жарып шығып, көлденең аяқталатын (ЖБКҰ) ұңғыларды қазу кезіндегі ұңғы оқпанының жобалық профильден ауытқуы туралы өндірістік мәліметтерді талдау нәтижелері берілген. Мұнда бұрғыланған көптеген ұңғылардың жобалық профрильден ауытқу жағдайында аяқталғанды анықталды. Инклинометриялық нақты өлшеу мәндерінің дұрыс толтырылмауынан туындаған белгісіздіктердің салдарынан көптеген ұңғы профилдері ПО «Petrel» аппаратына бағыттау түзетпесінсіз ( БТ) енгізілгендігі туралы анық белгілі болды. Яғни моделге салынған қате мәліметтердің әсерінен жобада белгіленген ұңғы түбінің орнынан ығысуы байқалды. Осы жағдайларды болдырмауға бағытталған тиесілі ұсыныстар жұмыстың түйіні түрінде берілген.

ТҮЙІн СөзДЕР: ұңғы профильдері, көлденең ұңғылар, жобаланған профильден ауытқу, инклинометриалық өлшеулер, бағыттау түзетпелері (БТ), ПО «Petrel», ұңғы түбінің модельдегі ауытқуы.

\section{ANALYSIS OF TRAJECTORY DEVIATIONS OF HORIZONTAL AND DIRECTIONAL WELLS FROM THEIR DESIGN PROFILES}

Zh. G. SHAIKHYMEZHDENOV*, doctor of technical science, professor of KazUTB, member of National Engineering Academy of RK, https://orcid.org/0000-0002-2290-1040

KAZAKH UNIVERSITY OF TECHNOLOGY AND BUSINESS

37A, Kayym Mukhamedkhanov st., Esil district, Nur-Sultan, Republic of Kazakhstan

The paper presents an analysis of field materials in deviations from the design trajectories of the boreholes when drilling directional horizontal wells (HW) and sidetracking with horizontal completion wells $(\mathrm{SHW})$ in the considered fields. The results indicate the presence of a large number of completed wells with deviations from the design profile. It has been observed that there is an incorrect filling of actual directional measurements, and also due to ambiguities in the filled-in data on measurements, well profiles in the Petrel software were loaded without directional correction (DC), which led to displacement of the bottom of many wells in the models. To prevent these cases, appropriate recommendations are given.

KEY WORDS: well profiles, horizontal wells $(H W)$, deviations from the design profile, directional measurements, "Petrel" software, direction corrections (DC), well bottomhole displacement in models.

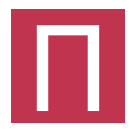

роводка горизонтальных и наклонно- направленных скважин осуществляются с целью вскрытия продуктивных пластов, где разработка традиционными вертикальными скважинами неэффективна. Встречающиеся при вскрытии осложнения при этом, в основном, заключаются в сохранении заданной траектории ствола скважины до проектной отметки.

Основным критерием оценки горизонтальных и наклонно- направленных скважин, заложенных для дальнейшей разработки вскрытой залежи является завершение строительством скважины, ствол которой проведен до забоя без отклонения от проектной траектории.

Проведенный анализ промысловых материалов проводки наклонно-направленных, горизонтальных скважин (ГС) и скважин по зарезке боковых стволов с горизонтальным окончанием (ЗБГС) по некоторым месторождениям показывает на наличие значительного их количества, завершенных с отклонениями от проектного профиля. Например, 


\section{БУРЕНИЕ}

в таблице 1, 2 и рисунок 1. представлены сведения по отклонениям проведенных стволов некоторых скважин от проектных профилей из числа рассматриваемых 126 скважин по месторождениям Жетыбай - 81 ГС, Каламкас - 45 ЗБГС.

Таблица 1 - Отклонение от проектного профиля горизонтальных скважин месторождения Жетыбай

\begin{tabular}{|c|c|c|}
\hline \multirow{2}{*}{ № скв. } & \multicolumn{2}{|c|}{ Отклонение от проектного профиля, ГС } \\
\cline { 2 - 3 } & По вертикали, $\mathbf{~}$ & На забое по горизонтали, $\mathbf{M}$ \\
\hline $\mathbf{4 4 1 6}$ & - & 53 \\
\hline $\mathbf{4 4 6 8}$ & 11 & 41 \\
\hline $\mathbf{4 4 7 2}$ & 4 & 50 \\
\hline $\mathbf{4 4 7 6}$ & 16 & 29 \\
\hline $\mathbf{4 4 7 7}$ & 9 & 55 \\
\hline $\mathbf{4 4 9 0}$ & 14 & 60 \\
\hline $\mathbf{4 4 9 8}$ & 3 & 70 \\
\hline $\mathbf{4 5 1 9}$ & 8 & 40 \\
\hline $\mathbf{4 5 2 5}$ & 20 & 11 \\
\hline $\mathbf{4 5 3 1}$ & - & 40 \\
\hline $\mathbf{4 5 4 4}$ & 2 & 50 \\
\hline $\mathbf{4 5 4 8}$ & 12 & 8 \\
\hline
\end{tabular}

Таблица 2 - Отклонение от проектного профиля при зарезке боковых стволов с горизонтальным окончанием по месторождению Каламкас

\begin{tabular}{|c|c|c|}
\hline \multirow{2}{*}{ № скв. } & \multicolumn{2}{|c|}{ Отклонение от проектного профиля, ЗБГС } \\
\cline { 2 - 3 } & По вертикали, м & На забое по горизонтали, м \\
\hline $\mathbf{1 2 2}$ & - & 140 \\
\hline $\mathbf{2 2 1 8}$ & - & 51 \\
\hline $\mathbf{3 3 5 8}$ & 15 & 24 \\
\hline $\mathbf{3 3 8 6}$ & 3 & 83 \\
\hline $\mathbf{3 4 0 5}$ & 4 & 146 \\
\hline $\mathbf{4 0 7 5}$ & 9 & 67 \\
\hline $\mathbf{5 0 3 1}$ & 2 & 41 \\
\hline
\end{tabular}

Для выяснения причин безуспешности вскрытия продуктивных горизонтов были детально рассмотрены геологические условия проводки горизонтальных скважин. Например, скважина № 4490 пробуренная в 2015 г. по проекту на горизонт Ю-7 проведена в кровельной части пласта. Начальный дебит составил 0,6 т/сут, а дебит на 01.03.2016 составил также 0,6 т/сут. Проницаемость согласно 3Д модели 50-150 $\mathrm{mD}$. Длина горизонтального участка (рисунок 2) составляет 200 м.

Высокая глинистость коллекторов, вскрытых в рассматриваемом интервале объясняют причину отсутствия промышленного притока. Аналогичные картины наблюдаются по многим рассмотренным скважинам, то есть отклонение траектории ствола от цели (или некорректное попадание в цель). 


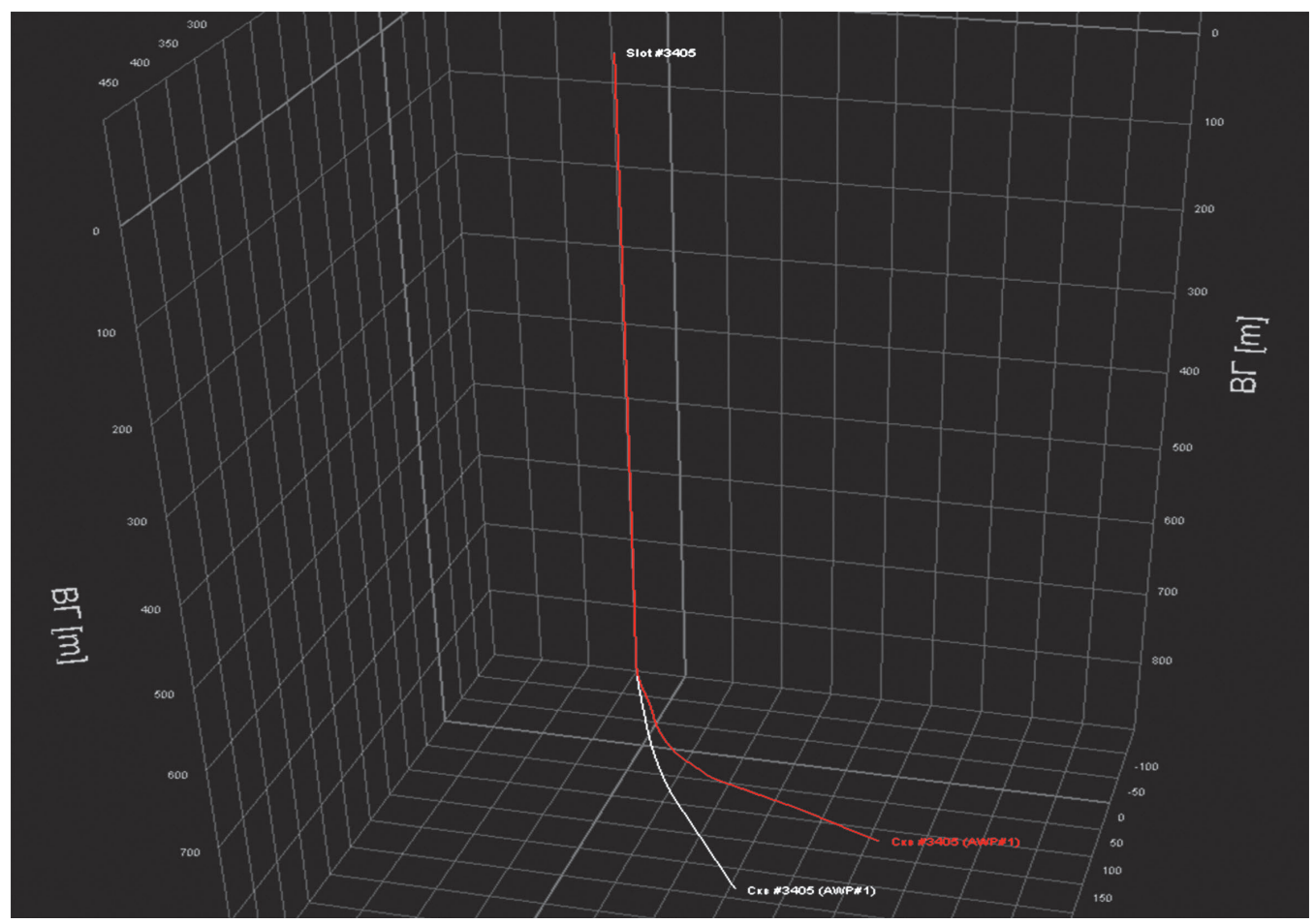

Рисунок 1 - Скважина № 3405 ЗБГС - Каламкас, расхождение от проектного профиля на забое равно $146 \mathrm{~m}$

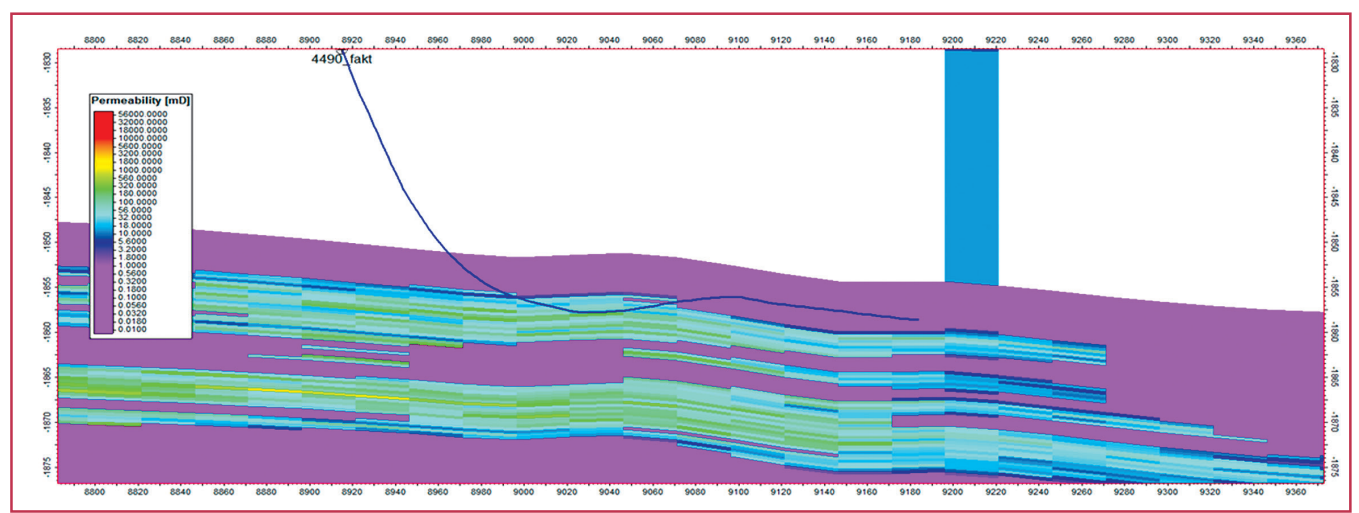

Рисунок 2 - Куб проницаемости. Фактический ствол скважины № 4490 в ЗД модели

При проведении анализа инклинометрических данных, представленных геофизическими компаниями и загруженных в ПО профилей скважин, были выявлены ошибки, которые привели к отклонениям траекторий от заданных профилей. Например, наблюдались отклонения при загрузке данных в ПО Petrel и выявлены неточности предоставленных данных по инклинометрическим замерам от геофизических компаний АО УПГФ по месторождениям Узень, Карамандыбас, Жетыбай, TOO TechnoTradingLtd по месторождению Каламкас и т.д. 


\section{БУРЕНИЕ}

Для выяснения указанных причин по отклонению фактических профилей от проектных были также проанализированы промысловые материалы по более 300 скважинам, пробуренных на месторождениях Узень и Карамандыбас в 2011-2017 годах. Для примера по анализу приняты данные инклинометрических замеров и профилей скважин, загруженных в ПО Petrel некоторых скважин по месторождениям Қарамандыбас, Узень, Қаламқас.

Как видно из таблицы 3, данные инклинометрии по скважине № 4592 Узень, замеренные АО УПГФ через магнитометрический инклинометр, содержат в себе магнитные азимуты, а в третьей колонке не указан, какой именно азимут (истинный, магнитный, дирекционный угол). В третьей колонке должен быть указан магнитный азимут.

И в итоге такие данные грузятся (таблица 4) в модели без поправок направления (ПН), что составляет примерно 6 градусов на рассматриваемые даты проведения замеров. Для того чтобы избежать путаницу, необходимо угол склонения называть поправкой направления или отклонением магнитной стрелки.

Таблица 3 - Инклинометрические измерения АО УПГФ по скважине № 4592

Заказчик: ТОО «Бургылау»

Скважина №4592 площадь: Узень

Диаметр скважины: 0.216 м. Глубина башмака: 225.0 м.

Угол склонения: 6.00 градусы минуты. Альтитуда: 95.91 м. Забой: 1188.2 м.

Исполнитель: АО «УПГФ»

\begin{tabular}{|c|c|c|c|c|c|c|c|}
\hline \multirow{3}{*}{$\begin{array}{l}\text { № } \\
1\end{array}$} & \multirow{2}{*}{\multicolumn{2}{|c|}{$\begin{array}{c}\text { Интервал, кол. } \\
\text { точек и дата } \\
\text { исследования }\end{array}$}} & \multirow{3}{*}{$\begin{array}{c}\text { Тип и номер } \\
\text { прибора, дата } \\
\text { проверки }\end{array}$} & \multicolumn{4}{|c|}{ Хар-ка ствола замера } \\
\hline & & & & \multirow{2}{*}{$\begin{array}{l}\text { Ствол } \\
\text { откр. ствол }\end{array}$} & \multicolumn{3}{|c|}{ ЛБТ | ТБПВ| УБТ } \\
\hline & $0-156$ & (17T) & & & 0 & 0 & 0 \\
\hline 2 & $100-650$ & (53T) & ИММН-60 №377 & через бур/инструмент & 0 & 0 & 0 \\
\hline 3 & $100-560$ & (47т) & ИММН-60 №377 & откр. ствол & 0 & 0 & 0 \\
\hline 4 & $500-800$ & (31т) & ИММН-60 №583 & откр. ствол & 0 & 0 & 0 \\
\hline 5 & $750-975$ & (24T) & ИММН-60 №583 & откр. ствол & 0 & 0 & 0 \\
\hline 6 & $500-1188$ & (70T) & ИММН-60 №584 & откр. ствол & 0 & 0 & 0 \\
\hline
\end{tabular}

Magnetic Azimuth

\begin{tabular}{|c|c|c|c|c|c|c|c|c|c|c|}
\hline $\begin{array}{c}\text { Глубина } \\
\text { м }\end{array}$ & $\begin{array}{c}\text { Угол } \\
\text { градусы }\end{array}$ & $\begin{array}{l}\text { Азимут } \\
\text { градусы }\end{array}$ & $\begin{array}{c}\text { Удлинен } \\
\text { м }\end{array}$ & $\begin{array}{c}\text { Абс } \\
\text { отметка } \\
\text { м }\end{array}$ & $\begin{array}{c}\text { Верт } \\
\text { глубина } \\
\text { м }\end{array}$ & $\begin{array}{c}\text { Смещение } \\
\text { м }\end{array}$ & $\begin{array}{l}\text { Дир. Угл } \\
\text { смещени } \\
\text { градусы }\end{array}$ & $\begin{array}{c}+ \\
\text { сервер } \\
- \text { юг, м }\end{array}$ & $\begin{array}{c}\text { +восток } \\
\text {-запад, } \\
\text { м }\end{array}$ & $\begin{array}{c}\text { Интен. } \\
\text { Градусы/10 м }\end{array}$ \\
\hline 0.0 & 0.00 & & 0.00 & 95.91 & 0.00 & & & & & \\
\hline 10.0 & 0.68 & & 0.00 & 85.91 & 10.00 & & & & & \\
\hline 30.0 & 0.44 & \multirow{8}{*}{$\begin{array}{l}193.92 \\
288.41 \\
300.41 \\
308.21 \\
311.98 \\
261.49 \\
358.22 \\
310.38\end{array}$} & 0.00 & 75.91 & 20.00 & & & & & \\
\hline & & & & & & & & & & \\
\hline & & & & & & & & & & \\
\hline & & & & & & & & & & \\
\hline & & & & & & & & & & \\
\hline & & & & & & & & & & \\
\hline & & & & & & & & & & \\
\hline & & & & & & & & & & \\
\hline 130.0 & 0.28 & 104.95 & 0.01 & -34.08 & 129.99 & 0.7 & 313.95 & 0.5 & -0.5 & 0.49 \\
\hline
\end{tabular}


Таблица 4 - Загрузка инклинометрических измерений по скважине № 4592 в ПО «Petrel» WELL TRACE PETREL

- WELL TRACE FROM PETREL

-WELL NAME: 4592

-WELL HEAD X-COORDINATE: 39586.20000000 (m)

- WELL HEAD Y-COORDINATE: $84870.81000000(\mathrm{~m})$

-WELL KB:

$95.91000000(\mathrm{~m})$

-WELL TYPE: unknown

- MD AND TVD ARE REFERENCED (-0) AT KB AND INCREASE DOWNWARDS

- ANGLES ARE GIVEN IN DEGREES

- XYZ TRACE IS GIVEN IN COORDINATE SYSTEM Null

- AZIMUTH REFERNCE UNDEFINED

- DX DYARE GIVEN IN GRID NORTH IN m-UNITS Grid Azimuth

- DEPTH (Z, TVD) GIVEN IN m-UNITS

\begin{tabular}{|c|c|c|c|c|c|c|c|c|c|}
\hline MD & $x$ & $\mathrm{Y}$ & z & TVD & DX & DY & AZIM & INCL & DLS \\
\hline 0.0000000000 & 39586.200000 & 84870.810000 & 95.9100000000 & 0.0000000000 & 0.0000000000 & 0.0000000000 & 0.00000000000 & 0.0000000000 & 0.0000000000 \\
\hline 30.000000000 & 39586.190763 & 84870.999620 & 65.911037727 & 29.998962273 & -0.009237274 & 0.1896198363 & \multirow{2}{*}{$\begin{array}{l}193.92000000 \\
288.41000000 \\
300.41000000 \\
308.21000000 \\
311.98000000 \\
261.49000000 \\
358.22000000 \\
310.38000000\end{array}$} & 0.4400000000 & 3.1572442055 \\
\hline & & & & & & & & & \\
\hline 130.00000000 & 39585.624584 & 84871.417051 & -34.08553727 & 129.99553727 & -0.575415659 & 0.6070511366 & 104.95000000 & 0.2800000000 & 2.4354708195 \\
\hline
\end{tabular}

По данным таблицьы 4 видно, как в ПО PETREL загрузили дирекционные углы в значениях магнитного азимута, хотя разница между ними должна быть равной 6,06 градусам.

Необходимо было загружать данные в ПО PETREL, с учетом поправки направления (ПН): (GridAzimuth)=(MagneticAzimuth) $+\mathbf{6 . 0 6}$

Например: GridAzim $(30 \mathrm{~m})=$ MagneticAzim $(30 \mathrm{~m})+6.06=\mathbf{1 9 3 . 9 2 + 6 . 0 6}=\mathbf{1 9 9 . 9 8}$

Инженерами АО УПГФ на скважине № 657 Карамандыбас (таблица 5) допущена грубейшая ошибка, прописывая угол склонения равным нулю, и не учитывая углы сближения меридианов между истинным севером и севером сетки. Угол склонения не может быть равным нулю в данной точке, так как магнитное склонение равно 7,18 градусов, а ПН =6,06 градусов. Необходимо было указать угол сближения меридианов: 7,18 - 6,06 = 1,12 градусов. приравниваться дирекционным углам (0 м, 3 и 8 колонки). Так, в третьей колонке указаны при «0м» истинные азимуты, поэтому они не должны быть равным дирекционным углам (3 и 8 колонки).

Аналогично по скважине № 4592 - Узень супервайзеры также некорректно заполнили данные по инклинометрии, дублируя ошибки заполнения геофизиков, не указывая какие именно азимуты заполняются. То есть, как ранее было отмечено, необходимо было написать, что это магнитные азимуты. Тем самым, эти ошибки могут привести к столкновениям при ЗБС, бурении горизонтальных и наклонно-на- 


\section{БУРЕНИЕ}

Таблица 5 - Ошибки операторов при заполнении данных инклинометрических измерений по скважине №657

Заказчик: НГДУ-4, ППД-4

Скважина № 657, площадь: Карамандыбас

Диаметр скважины: 0.216 м. Глубина башмака кондуктора: 592.2 м.

Существующие интервалы перфорации: 1359-1360 1363-1368

Угол склонения: 0,00 градусы' минуты.

Альтитуда: 215,05 м. Забой по заявке: 1440 м.

Доход прибора: 1435 м.

Инженер КИП: Ф.И.О.

\begin{tabular}{|c|c|c|cc|c|c|}
\hline № & $\begin{array}{c}\text { Интервал, кол. } \\
\text { точек и дата } \\
\text { исследования }\end{array}$ & $\begin{array}{c}\text { Тип и номер } \\
\text { прибора, дата } \\
\text { проверки }\end{array}$ & \multicolumn{2}{|c|}{ Хар-ка ствола замера } \\
Ствол & ЛБт | ТБПВ| УБт \\
\hline 1 & $0.0-1435$ 0-1434 & ИГН-73 №109 & в колонне & 0 & 0 \\
\hline
\end{tabular}

\begin{tabular}{|c|c|c|c|c|c|c|c|c|c|c|}
\hline $\begin{array}{c}\text { Глубина } \\
\text { м }\end{array}$ & $\begin{array}{c}\text { Угол } \\
\text { градусы }\end{array}$ & $\begin{array}{l}\text { Азимут } \\
\text { градусы }\end{array}$ & $\begin{array}{c}\text { Удлинен } \\
\text { м }\end{array}$ & $\begin{array}{c}\text { Абс } \\
\text { отметка } \\
\text { M }\end{array}$ & $\begin{array}{c}\text { Верт } \\
\text { глубина } \\
\text { м }\end{array}$ & $\begin{array}{c}\text { Смещение } \\
\text { м }\end{array}$ & $\begin{array}{c}\text { Дир. Угл } \\
\text { смещени } \\
\text { градусы }\end{array}$ & $\begin{array}{c}+ \\
\text { сервер } \\
- \text { юr, } \mathrm{M}\end{array}$ & $\begin{array}{c}+ \text { восток } \\
\text {-запад, } \\
\text { м }\end{array}$ & $\begin{array}{c}\text { Интенс. } \\
\text { Градусы/10м }\end{array}$ \\
\hline 0.0 & 0.00 & 203.15 & 0.00 & 215.05 & 0.00 & 0.0 & 203.15 & 0.0 & 0.0 & 0.00 \\
\hline 10.0 & 0.09 & 222.15 & 0.00 & 205.05 & 10.0 & 0.0 & 223.02 & -0.0 & -0.0 & 0.16 \\
\hline 140.0 & 0.24 & 144.86 & 0.00 & 75.05 & 140.00 & 0.3 & 193.70 & -0.03 & -0.1 & 0.07 \\
\hline
\end{tabular}

правленных стволов скважин, отклонениям при составлении 3D геологических и гидродинамических моделей.

В рассмотренных материалах инклинометрических замеров по месторождениям АО ММГ по скважине № 40 Алатобе также ошибочно не указываются принадлежность азимутов с учетом того, что замеры производились магнитометрическими инклинометрами. По материалам скважин № 760 Асар, №2729 Каламкас видно, что после замеров магнитометрическими инклинометрами, представленных от ТОО Technotrading Ltd инклинометрии столбик «Азимут» содержит именно «Магнитные азимуты», но в ПО Petrel эти данные вводятся как дирекционные углы.

При большом количестве профилей наклонно-направленных и горизонтальных скважин, как на рассмотренных месторождениях загрузка данных инклинометрии вводится без учета поправки направления (ПН), что является критичным и может привести к большим отклонениям от фактического расположения профиля скважин. В этих случаях необходимо строго проверять исходные и загруженные параметры инклинометрических данных.

Следует также отметить, что в ПО Petrel есть возможность указать истинные азимуты или дирекционные углы в инклинометрии скважины. Если указаны истинные азимуты, то учитывая систему координат и координаты устья скважины, программа автоматически высчитывает угол сближения меридианов и конвертирует истинные азимуты в дирекционные углы, то есть построение траекторий выполняется только в дирекционных углах.

Но так как во многих моделях месторождений ДЗО КМГ система координат “Undefined” (Неопределенная), что подразумевает в большинстве случаев условную систему координат СК66-геологическую, то необходимо загружать инклинометрию 
только (!) в дирекционных углах, так как программа не сможет корректно определить угол сближения меридианов в данной точке.

Таким образом, по рассмотренным месторождениям имеются большое количество, например, только по месторождениям Каламкас и Жетыбай по пробуренным 170 скважинам 88 (49 скв. Жетыбай и 39 скв. Каламкас), что составляет 52\%, оказались, завершенными с существенными отклонениями от проектного профиля, а также по одной скважине в техническом проекте отсутствует даже профиль ( №5747 Каламкас).

Отклонения от проектного профиля связано, в основном, кроме геологических причин и отсутствием геофизической информации в процессе бурения (LWD), от ошибочно представленных значений инклинометрических замеров, которые при составлении геологической модели загружались в ПО «Petrel» без внесения соответствующих поправок.

Таким образом, из рассмотренных выше материалов можно сделать следующие выводы:

1.Определено, что по месторождениям наблюдается наличие большого количества завершенных скважин с отклонениями от проектных профилей, которые приводят к значительным экономическим затратам, тем самым к снижению рентабельности предприятий.

2. Анализ, проведенный по инклинометрическим данным, представленных геофизическими компаниями и загруженных в ПО «Petrel» профилей скважин, показал на некорректные заполнения фактических замеров, которые привели к указанным выше отклонениям траекторий от заданных профилей.

3. Выявлены факты того, что из-за неясностей в заполненных данных об инклинометрических замерах, профили скважин в ПО Petrel загружались без поправки направления (ПН), например, на месторождениях Узень и Карамандыбас, равной 6 градусам. В итоге произошли смещения забоев многих скважин в моделях по отношению к заданным.

4. Определено, что не существует единой формы заполнения данных по инклинометрическим замерам, обеспечивающие надлежащие взаимодействия по отчетности по ним между заказчиками, геофизическими компаниями, проектировщиками и подрядчиками.

С целью недопущения вышеописанных ошибок и неточностей при заполнении инклинометрических замеров, нами предлагается следующее:

1. Геофизическим компаниям при предоставлении материалов Проектировщикам и Заказчикам инклинометрических данных следует:

- указывать принадлежность азимутов к дирекционным углам или к истинным;

- предоставлять технические характеристики используемых инклинометров для учета погрешностей приборов после загрузки инклинометрии в ПО и построения «Эллипса неопределенности» положения ствола скважины;

- указывать магнитное склонение, угол сближения меридианов, а также поправка направления ( ПН ).

2. Обязательно, чтобы Проектанты перед загрузкой в ПО данные инклинометрии (азимуты) переводили в дирекционные углы.

3. Использовать в практике предлагаемые «Единые формы заполнения инклинометрических замеров» (таблицы 6,7). 
Таблица 6 - Форма заполнения инклинометрических, замеров когда не используются условные системы координат

\begin{tabular}{|c|c|c|c|c|c|c|c|c|c|c|c|}
\hline \multicolumn{6}{|l|}{ Заказчик } & \multicolumn{3}{|c|}{ Система координат/зона } & & & \\
\hline \multicolumn{3}{|l|}{ Подрядчик } & & & & \multicolumn{3}{|c|}{ Широта/Долгота, град } & & & \\
\hline \multicolumn{3}{|c|}{ Месторождение } & & & & \multicolumn{3}{|c|}{ Координаты Y(С/Ю), X(B/3), м } & & & \\
\hline \multicolumn{3}{|l|}{ Скважина } & & & & \multicolumn{3}{|c|}{ Метод расчета профиля } & \multicolumn{3}{|c|}{ минимальной кривизны и т.д. } \\
\hline \multicolumn{3}{|c|}{ Ствол скважины } & & & & \multicolumn{3}{|c|}{ сближение меридианов, град } & & & \\
\hline \multicolumn{3}{|c|}{ Альтитуда стола ротора, $\mathrm{M}$} & & & & \multicolumn{3}{|c|}{ Поправка направления, град } & & & \\
\hline \multicolumn{3}{|c|}{ Альтитуда поверности земли, м } & & & & \multicolumn{3}{|c|}{ Магнитное склонение, град } & & & \\
\hline \multicolumn{3}{|c|}{ Конструкция скважины } & \multicolumn{9}{|c|}{$324 \times 9,5-30$ м, 245 ×8,9Д-600 м, 168×8,9E-1310 м (Пример) } \\
\hline \multirow[t]{3}{*}{ Дата отчета } & Дата замера & \multicolumn{3}{|c|}{ Интервал замеров, м } & Диаметр скважины, м & Состояни & ие ствола & Тип прибора & \multicolumn{3}{|c|}{ Ориентация на север } \\
\hline & & \multicolumn{3}{|c|}{0.500 (Пример) } & & открытый, 0 & обсаженный & ИМмн-60 (Пример) & \multicolumn{3}{|c|}{ магнитный север, истинный север } \\
\hline & & \multicolumn{3}{|c|}{ 500-1200 (Пример) } & & открытый, 0 & обсаженный & иммн-60 (Пример) & \multicolumn{3}{|c|}{ магнитный север, истинный север } \\
\hline \multirow[t]{2}{*}{$\begin{array}{c}\text { Глубина по } \\
\text { стволу, }\end{array}$} & $\begin{array}{l}\text { зенитный } \\
\text { үгол, град }\end{array}$ & $\begin{array}{c}\text { Магнитный } \\
\text { азимут, } \\
\text { град }\end{array}$ & $\begin{array}{c}\text { Истинный } \\
\text { азимут, } \\
\text { град }\end{array}$ & $\begin{array}{c}\text { Аирекционный } \\
\text { үгол, град }\end{array}$ & Абсолютная глубина, м & вертикальная & смещцение, м & $\begin{array}{l}\text { Аирекционный угол } \\
\text { смещения, град }\end{array}$ & $\begin{array}{l}+ \text { Север } \\
-10 \mathrm{r}, \mathrm{m}\end{array}$ & $\begin{array}{c}\text { +Boctok } \\
\text {-3апад, m }\end{array}$ & $\begin{array}{c}\text { Интенсивность } \\
\text { искривления, } \\
\text { град/10 м }\end{array}$ \\
\hline & & & & & & & & & & & \\
\hline
\end{tabular}

Примечание: Прикрепляются основные технические характеристики используемых инклинометров

Данная форма заполняется если не используются условные системы координат.

Таблица 7 - Форма заполнения инклинометрических замеров, когда используются условные системы координат

\begin{tabular}{|c|c|c|c|c|c|c|c|c|c|c|c|c|}
\hline \multicolumn{7}{|l|}{ Заказчик } & \multicolumn{6}{|c|}{ Система координат/зона } \\
\hline \multicolumn{3}{|l|}{ Подрядчик } & & & & & \multicolumn{3}{|c|}{ Широта/Долгота, град } & & & \\
\hline \multicolumn{3}{|c|}{ Месторождение } & & & & & \multicolumn{3}{|c|}{ Координаты Y(С/ю), X(B/3), м } & & & \\
\hline \multicolumn{3}{|c|}{ Скважина } & & & & & \multicolumn{3}{|c|}{ Метод расчета профиля } & \multicolumn{3}{|c|}{ минимальной кривизны и т.д. } \\
\hline \multicolumn{3}{|c|}{\begin{tabular}{|l|} 
Ствол скважины \\
\end{tabular}} & & & & & \multicolumn{3}{|c|}{ сближение меридианов, град } & & & \\
\hline \multicolumn{3}{|c|}{ Альтитуда стола ротора, м } & & & & & \multicolumn{3}{|c|}{ Поправка направления, град } & & & \\
\hline \multicolumn{3}{|c|}{ Альтитуда поверности земли, $\mathrm{m}$} & & & & & \multicolumn{3}{|c|}{ Магнитное склонение, град } & & & \\
\hline \multicolumn{3}{|c|}{ Конструкция скважины } & $324 \times 9$, &, $5-30 \mathrm{~m} ; 245 \times 8,9 \mathrm{~A}-6$ & $600 \mathrm{M} ; 168 \times 8,9 \mathrm{E}-1310 \mathrm{~m}(\Pi$ & (ример) & \multicolumn{3}{|c|}{ Угол разворота условных систем координат, град } & \multicolumn{3}{|c|}{ если используется } \\
\hline \multirow[t]{3}{*}{ Дата отчета } & Дата замера & \multicolumn{3}{|c|}{ Интервал замеров, м } & Диаметр скважи & ны, $M$ & Состояни & ие ствола & Тип и номер прибора & \multicolumn{3}{|c|}{ Ориентация на север } \\
\hline & & \multirow{2}{*}{\multicolumn{3}{|c|}{$\begin{array}{c}\text { 0-500 (Пример) } \\
\text { 500-1200 (Пример) }\end{array}$}} & & & открытый, 0 & ббсаженный & имМн-60 (Пример) & \multicolumn{3}{|c|}{ магнитный север, истинный север } \\
\hline & & & & & & & открытый, 0 & ббсаженный & ИММн-60 (Пример) & магнитн & ный север, & истинный север \\
\hline \multirow[t]{2}{*}{\begin{tabular}{|c|} 
Глубина по \\
стволу, м
\end{tabular}} & $\begin{array}{l}\text { зенитный } \\
\text { угол, град }\end{array}$ & $\begin{array}{c}\text { Магнитный } \\
\text { азимуг, } \\
\text { град }\end{array}$ & $\begin{array}{c}\text { Истинный } \\
\text { азимут, } \\
\text { град }\end{array}$ & $\begin{array}{c}\text { Дирекционный } \\
\text { угол, град }\end{array}$ & $\begin{array}{l}\text { Дирекционный угол в } \\
\text { условн. системе } \\
\text { координат, град }\end{array}$ & \begin{tabular}{|c|} 
Абсолютная \\
глубина, $\mathbf{M}$
\end{tabular} & \begin{tabular}{|c|} 
Вертикальная \\
глубина,
\end{tabular} & смещение, м & $\begin{array}{l}\text { Дирекционный угол } \\
\text { смещения, град }\end{array}$ & $\begin{array}{c}\text { +Cевер } \\
- \text {-Юr, M }\end{array}$ & \begin{tabular}{|c|} 
+Восток \\
-3апад, M
\end{tabular} & $\begin{array}{l}\text { Интенсивность } \\
\text { искривления, } \\
\text { град/10 м }\end{array}$ \\
\hline & & & & & если используется & & & & & & & \\
\hline
\end{tabular}

Примечание: Прикрепляются основные технические характеристики используемых инклинометров

Данная форма заполняется если используются условные системы координат.

\section{ЛИТЕРАТУРА}

1 Материалы по отчетам департамента «Технологии бурения и капремонта скважин» ТОО НИИ «ТД и Б» «Казмунайгаз» за 2015 -2017 гг.

2 Исаченко В.Х. Инклинометрия скважин. - М.: Недра, 1987. - С. 216. [V.H. Issachenko. Inklinometriya skvazhin. - M.: Nedra, 1987. - P. 216].

3 Кульчинский В.В., Григашкин Г.А., Ларионов А.С., Щебетов А.В. Геонавигация скважин. - М.: МаксПресс, 2008. - С. 312. [V.V. Kulchinskii, G.A. Grigashin, A.S. Larionov, A.V. Shebeov. Geonavinaciya skvazhin. -M.: MaksPress, 2008. - P. 312].

4 Калинин А.Г., Никитин Б.А.,Солодский К.М., Султанов Б.З. Бурение наклонных и горизонтальных скважин. - М.: Недра, 1997. - С. 648. [A.G. Kalinin, B.A. Nikitin, K.M. Solodskii, B.Z. Sultanov. Burenie naklonnyh i gorizontal'nyh skvazhin. - M.: Nedra, 1997. - P. 648].

5 Акбулатов Т.О., Левинсон Л.М., Салихов Р.Г., Янгиров Ф.Н. Расчеты при бурении наклонных и горизонтальных скважин. Учебное пособие. - Уфа: Изд-во УГНТУ, 2005. [T.O. Akbulatov, L.M. Levinson, R.G. Salihov, F.N. Yangirov. Raschety pri burenii naklonnyh i gorizontal'nyh skvazhin./ Uchebnoe posobie. - Ufa: Izdatel'stvo UGNTU, 2005.] 


\section{БУРЕНИЕ}

6 Калинин. А.Г., Кульчицкий В.В. Естественное и искусственное искрив- ление сквалжин. Учебное пособие для вузов. - Москва-Ижевск, 2006. - C. 640 [A.G. Kalinin, V.V. Kul'chickii. Estestvennoe i iskustvennoe iskrivlenie skvazhin / Uchebnoe posobie dlya vuzov. - Moskva-Izhevsk, 2006. - P. 640]

7 Доровских И.В., В.В. Живаева., С.В. Воробьев. Построение проектного и фрактического профилей скважины. Методические указания. Самарский Государственный Университет, 2010. - C. 50. [I.V. Dorohovskih, V.V. Zhivayeva, S.V. Voroby'ev. Postroenie proektnogo I fakticheskogo profilei skvazhiny./ Metodicheskie ukazaniya. Samarskii Gosudarstevnnyi Universitet, 2010. - P.50].

8 Hean Ed. How operators can improve performance of measurement while drilling systems// Oil and Gas. 1984. - vol. 82. - № 44. - P. 80-81, 84.

9 Кульчицкий В.В. Геонавигационные технологии проводки наклонно-направленных и горизонтальных скважин.: ВНИИОЭНГ, 2000. - С. 351 [V.V. Kul'chickii. Geonavigacionnye tehnologii provodki naklonno-napravlennyh i gorizontal'nyh skvazhin. / VNIIOENG, 2000. - P. 351] 